\title{
THE PERSONA OF THE JURIST IN SALMOND'S JURISPRUDENCE: ON THE EXPOSITION OF 'WHAT LAW IS ...'
}

\author{
Shaunnagh Dorsett and Shaun McVeigh*
}

\begin{abstract}
If Sir John Salmond is taken as being an inaugural or founding father of not only a law school, but also of a New Zealand jurisprudence, two questions arise: "What might have been inherited from Salmond's jurisprudence?" And, "How might that inheritance be received today?" This article offers a response to these questions by considering Salmond's jurisprudence in terms of a conduct of life organised around the office and persona of the jurist.
\end{abstract}

The law is the theory of things, as received and acted upon within the courts of justice, and this theory may or may not conform to the reality of things outside. ${ }^{1}$

It has been truly said that he who could perfectly classify the Law would have a perfect knowledge of the law. ${ }^{2}$

\section{INTRODUCTION}

This symposium on the life and work of John Salmond has been situated in terms of the dual themes of the inauguration of the teaching of law at Victoria University of Wellington Law School and the possibility of a contemporary New Zealand jurisprudence or jurisprudences. The publication of the second edition of Salmond's famous treatise or textbook on jurisprudence in 1907 is almost coincidental with his taking up of the inaugural chair of law at Victoria University in 1906. If we

* Faculty of Law, Victoria University of Wellington; School of Law, University of Melbourne.

1 John Salmond Jurisprudence: or the Theory of the Law (2 ed, Stevens \& Haynes, London, 1907) 18 [Jurisprudence 2 ed]; John Salmond Jurisprudence: or the Theory of the Law (7 ed, Sweet \& Maxwell, London, 1924) 82 [Jurisprudence 7 ed]. It should be noted that we have mainly concentrated on this work, rather than the less frequently read First Principles of Jurisprudence (Stevens \& Haynes, London, 1893) [First Principles]. Salmond himself did state that Jurisprudence superseded the earlier work: see preface. References are given to both the second and the seventh editions, unless otherwise stated. The second edition coincides with Salmond's arrival at Victoria and is more generally available than the first edition. The seventh edition is one of the last written by Salmond himself.

2 John Chipman Gray The Nature and Sources of the Law (2 rev ed, Beacon Press, Boston, 1921) 3. 
take Salmond as being an inaugural or founding father of not only a law school, but also of a New Zealand jurisprudence, what might have been inherited from his jurisprudence, and how might that inheritance look in contemporary times? This article offers one response to that question, by considering Salmond in terms of a conduct of life, or at least the conduct of life organised around the office and persona of the jurist.

Questions of inheritance and conduct of life are rarely asked of Salmond's treatise on jurisprudence. After all, Salmond has been claimed as a (colonial) son of the modern schools of positivism and analytical jurisprudence and neither of these schools is much noted for its concern with inheritance, justice or the conduct of life. However, this view perhaps relies too heavily on philosophical polemics that dispute the claims of jurisprudence in the court of metaphysical and critical reason or believe too strongly in the claims of a legal science that can produce meaning without institutional place or responsibility. Neither account can be uncritically accepted. In this article, however, Salmond's jurisprudence is re-cast in the language of office, persona and role. At the risk of anachronism, this returns jurisprudence to a genre of analysis that has formed a large part of the discourse of the legal tradition. On the one hand it draws on a Ciceronian tradition of legal discourse that considers the duties and responsibilities of the jurist both in terms of the character and prudence of the jurist and in terms of a training in legal science. On the other hand, office is also the central feature of the institutional arrangement of mediaeval and early modern government in Europe.

The brief of this article is narrow. It seeks to show how questions of office continue to shape Salmond's jurisprudence. It does so largely as a matter of intellectual history. Focusing on the office and persona provides a point of organisation which more firmly links $19^{\text {th }}$ century jurisprudence to its history, rather than with present debates. In particular, the focus on the office and persona of the jurist, rather than the doctrinal content of Salmond's work, allows both an examination of the activity that establishes the discipline of writing jurisprudence and of the particular way in which Salmond elaborates the office and persona of the jurist. To do this Salmond's Jurisprudence - and by analogy, English analytical jurisprudence - is considered as, in part at least, elaborating a training for office. In order to draw out the questions of conduct that Salmond addresses, this article has been divided into four parts. The first three re-consider aspects of the ways in which Salmond's jurisprudence opens up an account of office and the persona of the jurist, and the last provides some concluding comments by way of commentary. The first part briefly looks at the concepts of office and persona. The second part then considers the office of the jurist as understood in terms of the genres of legal writing through which Salmond develops his account of legal science. The third part considers some of the uses to which the persona of the jurist is put in the conceptual ordering of what law is and the relations between the administration of justice, civil law and the State. The final part concludes with some brief comments on the contemporary inheritance of Salmond's conduct of the life of the law. 


\section{OFFICE, PERSONA, ROLE}

The language of office is perhaps more familiar to mediaeval and early modern thinking about law and government than it is to the $19^{\text {th }}$ century. Ernst Kantorowicz's studies of the Office of the Crown in the King's Two Bodies provided one of the influential accounts of office. ${ }^{3}$ Kantorowicz marked out the differences between the office of King, with its duties, responsibilities, rights of actions, rituals, attributes and deportments, and the person (persona) of the office holder. The office of King was not an isolated example. More generally, mediaeval and early modern government, church, and public life were structured through a broad network of offices. ${ }^{4}$ Such offices were institutionalised and persons were formally inducted by the administering and swearing of oaths. The oath often defined role: it provided the responsibilities of office, as well as the liberties, and hence, a means to assess conduct. ${ }^{5}$ The judge is a familiar example. From the mid fourteenth century, the judiciary swore to do "equal law and execution of right to all ... rich or poor" and "not to take fee nor robe of any man ... [nor] gift or reward by themselves". The modern oath echoes these concerns. ${ }^{6}$ The office then is determined by its purpose and limits, again often defined by the oath. For judges, the limits and bounds of the office is the administration of the law equally and impartially to all.

If office is the status, then the persona is the manifestation or expression of office - the way a person fills that office. For Condren "persona is an authentic type carried by a physical body": for Kantorowicz the natural body of the King. The persona carries the qualities which best suit the purpose and recognise the limits of office. ${ }^{7}$ In the context of $17^{\text {th }}$ century English government Condren contrasts the institutionalised office with the social office, those, for example, of the intellect: the poet, the rhetor and the philosopher. ${ }^{8}$ While devoid of the ceremony and taking of oath that accompanied institutionalised offices, the taking of a social office can nevertheless still carry responsibilities and obligations which define persona, although the distinction between office and persona becomes harder to hold. Here the persona lies in responsibilities to audience. The question of how the persona sees those responsibilities is bound to the purposes and limits of office. Persona

3 Ernst Kantorowicz The King's Two Bodies: A Study in Medieval Political Theology (Princeton University Press, Princeton, 1957).

4 Conal Condren "The Persona of the Philosopher and the Rhetorics of Office in Early Modern England" in Conal Condren, Stephen Gaukroger and Ian Hunter The Philosopher in Early Modern Europe: The Nature of a Contested Identity (Cambridge University Press, Cambridge, 2006) 66-89.

5 Ibid.

618 Edw III, c 4; 20 Edw III, c 1. See Wilfred Prest "Judiciary Corruption in Early Modern England" (1991) 133 Past and Present 67. In the modern context see Oaths and Declarations Act 1957 (NZ) s 18.

7 Condren, above n 4, 66 .

$8 \quad$ Ibid, 67. 
here then is a type, formed in part by character attributes and intellectual capacities, and in part by performance, and limited by the means and ends of office.

While in the $19^{\text {th }}$ century there are clearly a number of judicial and other offices of government, it is not so simple to argue that there is a distinct office of jurist. However, the language of office and jurist could still be found in, for example, the preface to Pound's Interpretations of Legal History, where it was noted that "Dr Pound's enlightened conception of the jurist's office is, again, one of the valuable contributions which he makes to juridical science". The author continues: "to [Pound] the jurist is - or at least ought to be - a creative and moulding force in legal progress". 9 Nevertheless, the office of jurist should be considered more of a social office than one that is fully instituted. It was certainly not one invested by oath. However, jurisprudence in $19^{\text {th }}$ century England, dominions and colonies, as in other times and places, produced its own accounts, often competing and rival accounts, of how to conduct oneself in relation to law. Its commentaries, digests, elements, essays, institutes and theories were engaged in a variety of tasks of instruction, scientific organisation, reform and polemic. Salmond's Jurisprudence: or the Theory of the Law is no different for all that it is presented as an analytical science of the first principles of law. In par,t then, the first question is how Salmond understood the office, with all its responsibilities and duties, as well as its limits, of the jurist.

\section{OFFICE, LEGAL SCIENCE AND THE GENRES OF JURISPRUDENCE}

Office can be considered in two aspects. First, the office of jurist is an office of State (civis). Second, the office is practiced through legal science. Here we link the office of the jurist to the forms of legal science by suggesting that the genres of jurisprudence delimit an office as much as a method of organisation and exposition of legal materials. For Salmond, legal science instantiates the purposes and limits of the office of jurist, as just as much as it does the purposes and limits of the law itself. Jurisprudence enables law to be viewed and practiced as a science rather than as a "repellent mystery" - repellent either because it is metaphysical or because it is a morass of undigested case law. ${ }^{10}$ This theme, along with the need to organise the office and persona of the jurist in terms of the civil law of the State, provides the central though not sole point of organisation of the legal office and persona of the jurist and of legal science.

\section{A Office and the Administration Of Justice}

Compared to the office of the judge, that of the jurist in common law jurisdictions has always been difficult to place. As some have pointed out, in comparison to the continental civilian tradition, the status of the common law jurist is less clearly defined. ${ }^{11}$ In part, no doubt, this is because of the

9 HD Hazeltine "Preface" in Roscoe Pound Interpretations of Legal History (McMillan Company, New York, 1923) xiii.

10 Jurisprudence 2 ed, above $\mathrm{n}$ 1, Preface.

11 RC Van Caenegem The Birth of the Common Law (Cambridge University Press, New York, 1973). 
particular divide of legal education between the Inns of Court, dominated by the judiciary, and the university, dominated by the church. One result is that in the $19^{\text {th }}$ century there is no clearly delimited office of jurist with associated responsibilities and obligations. ${ }^{12}$ As a social or intellectual office, the office of the jurist requires some historical reconstruction. To ask what is the institution and audience of the jurist helps to identify some of the situations in which the jurist works. However it is also necessary to ask this in order to frame the issues in terms of the responsibilities or duties of the jurist.

Like the social office of the philosopher or actor, the office of jurist is general and can be occupied in a number of different ways. ${ }^{13}$ However, compared to such offices, the office of jurist, for Salmond, is less diffuse. As a lawyer Salmond himself had a number of roles: jurist as university person; jurist as educator; jurist as State functionary; jurist as legal advisor. Not all aspects of the office can be traced here. All, however, are concerned with the administration of justice and with the administration of the justice of the State.

For Salmond, the jurisdiction of law is the administration of justice. Salmond locates the fundamental conception of law in the State, rather than the sovereign. The State role is that of the administration of justice. His definition of law is "the body of principles recognised and applied by the State in the administration of justice". ${ }^{14}$ Law is "justice speaking to men by the voice of the state". ${ }^{15}$ It is a perfect union of might and right: "societies can exit only under the shelter of the state and the law and the justice of the state is a permanent and necessary condition of peace, order and civilisation". ${ }^{16}$ Existentially, however, the administration of justice precedes law. In fact, not only is law subsequent to the administration of justice, it is "secondary and unessential". ${ }^{17}$ Salmond's reversal of what is the usual order - law logically precedes the organs of justice - proceeds from his conception of the State. For Salmond, the primary function of the State is to "maintain right, to uphold justice, to protect rights, to redress wrongs." 18 Law is merely the pre-established and authoritative rules which judges apply in the administration of justice. In so doing, the judges walk a

12 See Ian Hunter Rival Enlightenments: Civil and Metaphysical Philosophy in Early Modern Germany (Cambridge University Press, Cambridge, 2001).

13 Condren, above n 4, 67-68.

14 Jurisprudence 2 ed, above n 1, 9; Jurisprudence 7 ed, above n 1, 39.

15 Ibid, 2 ed, 50; 7 ed, 52.

16 Ibid, 2 ed, 67; 7 ed, 113.

17 Ibid, 2 ed, 13; 7 ed, 40.

18 Ibid. 
"pre-determined path". Judges cannot follow their own conscience, they have no free will or discretion. There is no private judgment: ${ }^{19}$

The law is the wisdom and justice of the organised commonwealth, formulated for the authoritative direction of those to whom the commonwealth had delegated its judicial functions. What a litigant obtains in the tribunals of a modern and civilised state is doubtless justice according to law, but it is essentially and primarily justice and not law. ... Justice is the end, law is merely the instrument and its means; and the instrument must be defined by reference to its end.

If this situation marks the office of the judge, then a first take on office for the jurist might be found in their contribution to the development of a legal system through the "progressive substitution of rigid pre-established principles for individual judgment."20 For Salmond "the great aggregation of rules which constitutes a developed legal system is not a condition precedent of the administration of justice, but a product of it. ... Justice becomes increasingly justice according to law, and courts of justice become increasingly courts of law."21 However, while the office of judge and jurist are at the centre of the elaboration, the legal meaning of State-backed force in the interests of justice, the office of the jurist, for Salmond, is also delimited in other ways.

\section{B Institutions and Audiences}

One audience then for the jurist is the judge. The relationship in Salmond's work of the social office of jurist to that of the instituted office of judge is never clearly articulated. There is clearly some movement between the two. The office of the judge is not assimilated to that of the jurist. However, part of being a judge is to be a jurist (and in some cases vise versa). In Jurisprudence, Salmond attributes priority to the office of judge in matters of judgment. It is, after all, the judge who makes law: "[i]n practice, if not in theory, the common law of England has been created by the decisions of English judges". While on the continent or in Roman law the textbook and the law reports "are both instruments for the persuasion of judges", in English law, the rule of precedent gives authority to the reports and hence the judges. ${ }^{22}$

It seems clear that we must attribute this feature of English law to the peculiarly powerful and authoritative position that has been at all times occupied by English judges.

However, by 1922, and "The Literature of Law", the relationship seems to have settled into a reasonably orthodox reciprocal relationship: judges 'provide' precedents and someone must interpret, clarify and systematise. In "The Literature of Law", Salmond issues a plea for the

19 Ibid.

20 Ibid, 2 ed, 14; 7 ed, 4.

21 Ibid.

22 Ibid, 2 ed, 160-161; 7 ed, 187-188. 
simplification of the law. He notes the sheer volume of literature, particularly in the United States, and the exhaustive expounding in works of even comparatively small branches of the law. He concludes that "it is not too much to say that the position will soon become intolerable". ${ }^{23}$ What was required, according to Salmond, was the formulation of a comprehensive code. That task could only be undertaken by the legal profession itself: bar associations, law schools, universities of both the US and Britain. These are the "experts" of the law, required to interpret and lay down precedent as determined by the judges. What was needed was the abstraction of general principles from the laborious detail of the law books. Only then could the law become 'scientific'. ${ }^{24}$ However, that abstraction, although to be embodied in a code, could not take the form of even the most "scientific and complete of foreign codes ... the civil code of Germany" but must embody the Englishness of the unwritten common law. ${ }^{25}$ It is not only the role of the jurist, but the responsibility of the jurist, to provide that clarification through the exposition of fundamental principles. In this respect, it is the jurist as legal scientist who represents the meaning of the law. It is interesting that as a lawyer, writer and educator, Salmond seems to attribute more priority to the office of judge than he attributes many years later when he has become a judge himself. ${ }^{26}$

The movement between judge and jurist in Jurisprudence may explain in part Salmond's eclectic use of materials and sources, a matter returned to later. Suffice it to say here that his reliance on the Pandectists and others contributed to a 'shoring up' of the office of the jurist vis-à-vis that of the judge. Legal science and the role of the legal scientist gave an expertise to the office of jurist which was different from that of the office of judge. Legal science can be seen as a training for the office of jurist. Conversely, of course, office gave shape to legal science.

There is little doubt that for Salmond jurisprudence, an emergent university discipline in common law jurisdictions, forms a central part of his conception of the office of jurist. Legal science was instantiated through jurisprudence. If jurisprudence is the substantive element, then the practice of education is its performance. ${ }^{27}$ In $19^{\text {th }}$ century England, the office of the jurist began to be more closely associated with the academy, although not always with the university. From the

23 John Salmond "The Literature of the Law" (1922) 22 Columbia Law Review 197, 199 ["Literature of the Law"].

24 Ibid, 201-202.

25 Ibid, 200.

26 It is true that Salmond's comments on the priority of the judge still appear in the $7^{\text {th }}$ edition, as late as 1926 . However, these must be read in conjunction with later, extraneous material. Moreover, it is noticeable that Salmond rarely simply modifies text through the editions. Rather, he adds material and then removes entire sections or chapters once they have been judged to be no longer relevant or entirely superseded.

27 See Marcel Senn "Legal Education in England and the German Historical School of Law in the Nineteenth Century" in Andrew Lewis, Paul Brand and Paul Mitchell (eds) Law in the City: Proceedings of the Seventeenth British Legal History Conference, London, 2005 (Four Courts Press, Dublin, 2007). 
1850s onwards, universities began to appoint professional legal educators in numbers. As Sugarman has pointed out, if academics were to establish themselves as one of the new professions of the latter half of the $19^{\text {th }}$ century, they needed to carve out and assert a body of expertise. What academics believed that they offered the profession was the ability to create order and cohesion through the organisation of the law into, and the teaching of, general principles that underlay the law. ${ }^{28}$ According to Sugarman: "[t]hey showed that the grubby, disorderly world of the court room and law office could ... be regarded as 'science in action'. ... Here then was the raison d'être of the new professional jurist and university legal education." 29 As a consequence, one of the dominant legal tasks of legal education and scholarship became the "exposition, conceptualization, systematization and analysis of existing legal doctrine." 30 Many members of the 'analytical school' held significant academic posts. Austin, of course, held the foundation Chair of Jurisprudence in the university of London. Holland held the Chichele Chair in International Law and Diplomacy at Oxford. Pollock was Professor of Jurisprudence at Oxford, while Sir William Markby became a Reader in Law at Oxford University on his retirement from the High Court in India.

The general audience for jurisprudence was for the most part students who would take up positions of office within institutional life. In the $18^{\text {th }}$ and $19^{\text {th }}$ centuries this would have involved those relating to the administration of justice in relation to the State (civil and military) and the church, as well as commerce and the management of estates. Addressed to this audience, jurisprudence might be viewed as it was in the $18^{\text {th }}$ century: as a branch of politics, morality, and political economy. John Locke's Treatise on Government, Adam Smith's Wealth of Nations, Jeremy Bentham's Principles of Legislation and, more latterly, Henry Sidgwick's The Elements of Politics, might all be considered works of jurisprudence in so far as they organised their considerations of the justice and the State (civis) around, and inherit, the topics of the early modern natural law tradition. ${ }^{31}$ However, $19^{\text {th }}$ century English, commonwealth and colonial jurisprudence also had two rather more specific audiences: those of the legal practitioners and university scholars. ${ }^{32}$

28 David Sugarman "Legal Theory, the Common Law Mind and the Making of the Textbook Tradition" in William Twining (ed) Legal Theory and Common Law (Blackwell, London, 1986) 29.

29 Ibid, 29-30. See also Neil Duxbury "Why English Jurisprudence is Analytical" (2004) 57 Current Legal Problems 1 who raises a similar point in terms of the "epistemic requirements" of the new university system: 45.

30 Sugarman, above n 28, 31.

31 John Locke Two Treatises of Government (Everyman, London, 1994 (1690)); Adam Smith Inquiry into the Nature and Causes of the Wealth of Nations (Everyman, London, 1991 (1776)); Jeremy Bentham An Introduction to the Principles and Morals of Legislation (Pickering, London, 1823 (1780)); and Henry Sidgwick The Elements of Politics (McMillan \& Co, London, 1891).

32 On Salmond's role in educating the judiciary as Solicitor-General see Mark Hickford's piece in this collection. See also Stefan Collini Public Moralists: Political Thought in Intellectual Life in Britain, 18501930 (Clarendon Press, Oxford, 1991). 
Salmond undoubtedly took seriously his role as a member of the academy and of the professoriate. At Victoria University he taught a number of courses: jurisprudence; Roman law; international law, conflicts and constitutional law and history. As he stated in his preface, Jurisprudence is "written primarily for the use of those students of law who are desirous of laying a scientific foundation for their legal education." ${ }^{33}$ These courses were, of course, standard fare at home and in the colonies. What was important, however, was not just the topics taught, but the communication of a particular type of knowledge in a certain type of way. Salmond's work, however, was not just written for students. From early in his career as a lawyer, Salmond published regularly: not just books, but commonly in the Law Quarterly Review. ${ }^{34}$ His audience was considerably broader and he maintained throughout his career correspondence with other jurists of the day, notably Maitland.

The audiences of the jurist, therefore, are wide and diffuse: the judiciary; the student; members of the academy; the profession. What holds these general audiences together and gives shape to the office of jurist, it is suggested, is the responsibilities of the jurist towards that audience. For Salmond, the primary responsibility of the jurist is the exposition of the law. It is this task, in turn delimited by the shape of the 'law' (what law is. ...), which defines the limits of office.

\section{Legal Science and Social Office}

If the office of jurist is general, then in order to give it some specificity, it needs to be tied to the practice of the jurist and the expertise of the jurist. For Salmond, legal expertise is closely bound to legal science and the privileged site of legal science is jurisprudence. The delimitation of legal science is the proper scope of the office of jurist. In developing this account, two elements are considered: first anti-metaphysics; and, second, legal science as the abstraction of general principles from law. Together these can be seen as the distinct mark of Salmon's office as jurist. This second part is examined in two aspects: here through institutional history, and in Part III through the persona of the jurist.

The question of how the science of legal science might be ordered became a central concern of the $18^{\text {th }}$ and $19^{\text {th }}$ centuries. In continental Europe, writers attempted to identify various bases for certain, secularized knowledge, including legal knowledge, derived from reason. In the $19^{\text {th }}$ century this culminated in debates between various schools - rationalism, positivism and historicism: debates with which English and American scholars were more than familiar. For the 'English' jurisprudence of the $19^{\text {th }}$ century these accounts of legal science are entwined in an antimetaphysical polemic. In the $17^{\text {th }}$ and $18^{\text {th }}$ centuries, this polemic engaged scholastic Aristotelian

33 Jurisprudence 2 ed, above n 1, Preface.

34 Details of his publications can be found in Alex Frame Salmond: Southern Jurist (Victoria University Press, Wellington, 1995) Appendix A. It is beyond the scope of this article to further consider his correspondence. However, details of this can also be found in Salmond: Southern Jurist. 
metaphysics. The immediate context of this engagement was the mastery of the political settlement of sovereign territorial States and the displacement of the authority of sectarian and confessional dispute. ${ }^{35}$ In the $19^{\text {th }}$ century, the anti-metaphysical concerns were more diffuse. For Salmond the anti-metaphysical position often seems directed against the Kantian jurisprudential tradition although this, as will be suggested, is far from clear. ${ }^{36}$

In the $17^{\text {th }}$ century, Pufendorf, amongst others, initiated a modern natural law jurisprudence by and large as an attack on a certain kind of metaphysics, particularly church metaphysics and the insistence that somehow there were transcendent values to be had in relation to law. This jurisprudence specifically tried to give an account of a State-based jurisprudence which was designed to exclude the higher authority of religion. In order to do that, it was necessary not simply to have a conceptual account, but also to train a cadre of lawyers, civil servants and academics not to think transcendently, not to get caught up in religious dispute, not to get too enthusiastic about questions of conscience and personal belief. This natural law jurisprudence in a sense produces a worldly ethic, a worldly conduct of life directed towards government of society and not government of the soul. Its concerns were not those of conscience but of the government of conduct and the conduct of government. ${ }^{37}$ And within that conduct, Pufendorf, for example, develops an account of office and role and indirectly an account of character appropriate to fill that office, a matter returned to later. Salmond paints himself as an anti-metaphysician. However, it is not that Salmond rejects entirely the relationship between law and justice but rather that a certain worldly 'English' attitude must be taken toward it. What might also be taken is the centrality of the State and civil administration to any account of jurisprudence.

Salmond makes a firm distinction between metaphysics and the investigation of the first principles of law. He stated that "much of the continental tradition of jurisprudence has a metaphysical aspect very alien to English modes of legal thought." 38 The nature of this firm

35 See generally David Saunders Anti-Lawyers: Religion and the Critics of Law and State (Routledge, London, 1997).

36 How the themes of State-formation and anti-metaphysical jurisprudence are to be related has itself been the subject of dispute. For some, the history of jurisprudence is itself a part of the theoretical understanding of law. As such, it is best presented either in terms of the development of legal knowledge or of legal reason. The form and content of jurisprudence are to be understood from within the domain of philosophy. For others, the history of jurisprudence is considered in terms of its institutional arrangements and commitments.

37 Jeffrey Minson Questions of Conduct (Macmillan Press, London, 1993) 5.

38 Jurisprudence 7 ed, above n 1, 3. Oddly, in other parts of Jurisprudence Salmond approves of this "continental method". See, for example, his discussion of legal rights in Chapter 10 in both the second and seventh editions. See also Salmond's comments on metaphysics in "The Literature of the Law", above n 23, 204-205. 
distinction is not elaborated. What might these first principles be? In the seventh edition, Salmond defines jurisprudence in the following way: ${ }^{39}$

[Jurisprudence] is the science of first principles of the civil law. It is not possible, indeed, to draw any hard line of logical division between those first principles and the remaining portions of the law. The distinction is one of degree rather than of kind.

While the content of the first principles is unclear, their organisation is not. Salmond organises first principles according to a tri-partite distinction, although the terms used change between the second and seventh edition. In the second edition, the distinction is made between the systematic, historical and critical. ${ }^{40}$ By the seventh edition, this has become analytical, historical and ethical. Analytical jurisprudence is "to analyse without reference either to historical origin or development, or to their ethical significance, or validity, the first principles of the law." ${ }^{41}$ Historical jurisprudence is concerned with "general principles governing the origin and development of law ... and in the second place with the origin and development of those legal conceptions and principles which are so essential in their nature as to deserve a place in the philosophy of law." ${ }^{42}$ Finally, ethical jurisprudence "deals with the law from the point of view of its ethical significance and adequacy." It deals with "the purpose for which [law] exists and the measure and manner in which that purpose is fulfilled." 43 For Salmond, "the purpose and end of law may be said generally to be the maintenance of justice within a political community by means of the physical force of the state." 44

Salmond elects to follow the English way, concentrating on the analytical. He discards the historical and the ethical as too 'continental'. For Salmond, analytical jurisprudence is the "...[i]ntellectual content of the law as it actually exists." Notably, in Salmond's First Principles, jurisprudence is categorically separate from law - a different intellectual activity. ${ }^{45}$ By the time of Jurisprudence it has become an abstraction, but not essentially different from law. Jurisprudence (as termed theoretical or general jurisprudence) can be distinguished from "the more practical and

39 Jurisprudence 2 ed, above n 1, 4; Jurisprudence 7 ed, ibid, 2.

40 Jurisprudence 2 ed, above n 1, 3. Systematic "deals with the present; its purpose is the exposition of the legal system as it now is"; historical "deals with the past; it is concerned with the legal system in the process of its historical development"; critical "deals with the ideal future; it expounds the law not as it is or has been, but as it ought to be". The first is "legal exposition"; the second "legal history" and the third "the science of legislation". Notably, it is the final limb of the tri-partide which shifts somewhat between the second and seventh editions, reflecting the thematisation of ethics in later editions: see below.

41 Jurisprudence 7 ed, above $\mathrm{n} 1,5$.

42 Ibid, 6.

43 Ibid, 7.

44 Ibid, 7.

45 Salmond The First Principles of Jurisprudence, above n 1, 3. 
special departments of legal study", although the "boundaries are not capable of being traced with logical precision."46 However, even if the relationship is unclear, Salmond is certain that the abstraction of first principles is a "distinct department of "scientific inquiry". Theoretical jurisprudence deals with law's "ultimate conceptions". It attributes "value to the abstract and the general." 47

Why then English jurisprudence? Why the English way? This has much to do with naming and with the meaning of 'law' and of 'right'. For Salmond, it is significant that, unlike European languages which make a distinction between ius and lex, English has no paired terms, only 'law'. The European tradition ties ius to both law and justice, "it has an ethical as well as a juridical application." 48 In English, law has "a purely juridical application." 49 Law creates oblivion of the real distinction between law and justice: "justice in itself, and as such, has no claim to the name of law." 50

Jus is law looked at from the point of view of right and justice; lex is law looked at from the point of view of authority and force. jus is the rule of right which becomes law by its authoritative establishment; lex is the authority by virtue of which the rule of right becomes law. Law is jus in respect of its contents, namely the rule of right; it is lex in respect of its source, namely its recognition and enforcement by the State.

The English 'right' has also "parted company with its Continental relatives." It has "remained physical and ethical, being excluded from the legal sphere by the superior convenience of the English law."51 This is the nature of English law and the office of the English jurist is tied to English law. The English are analytical because nomenclature requires them to be. This then is one limit of the office of the jurist: the task of the jurist is tied to the limits of law. Law is law so speaking, not ethics, nor justice nor right. And it is the task of the jurist to be the expositor of the law.

If for Salmond the negative is metaphysics, then the positive is exposition, and the analytical gives exposition. This is what it means to be an English writer for Salmond. What then is exposition? Exposition is a combination of categorisation and style. Salmond is drawn to the Institutionalist writings because they give a system of classification: they provide a way to get rid of

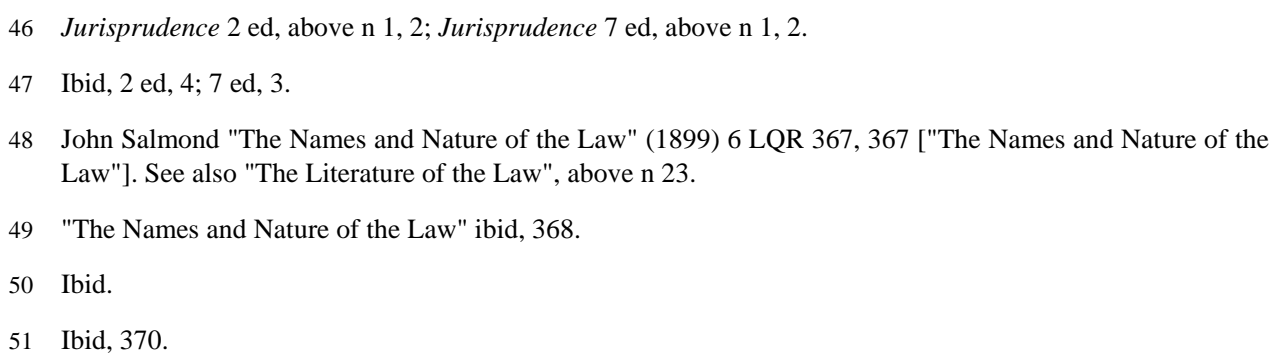


the "repellent-mysteries", in other words, to systematise and organise. Salmond does not, therefore, truly reject the 'continental', but looks to its classification and organisation, stripped of the metaphysical component. In essence, however, Salmond identifies himself as an English treatisewriter, although what this might mean, it is suggested, is to be quite eclectic. Salmond is selfavowedly analytical, but his sources present a more complex story. For example, Salmond linked his account of general jurisprudence to both the scholastic jurisprudence of Richard Hooker (and indeed Wolff) and a range of jurists and political philosophers whose work draws on the German historical school and the English idealist tradition. ${ }^{52}$ He also draws upon the treatises of Hale, the lectures of Blackstone and the natural law jurisprudence of Hobbes, to mention a few. Salmond is obviously conscious of, and unconcerned by, the eclectic nature of his sources. Appendix VII "Authorities" not only provides a bibliography, but comments on many individual scholars and works. Hooker's Ecclesiastical Polity, for example, is "[r]emarkable as one of the earliest presentations in the English language of the general theory of law. Hooker's doctrine is essentially that of scholastic philosophy." 53

The treatise has a long and venerable history in English jurisprudence. Hale's History of the Common Law is often viewed as the first work to see the common law as a body based on unified principle: 54 "[his] work sought to reconcile the political and historical polemics with a legal theory of the nature of the common law... ."55 Works were primarily remedially focused, and tended to list the law. The common law was still based in procedure and as a result there were many practitioners' texts which focused on writs, pleas and their precedents. ${ }^{56}$ Law was viewed by many as a "source based system of positive rules ... and a guide to conduct." ${ }^{57}$ Thus, law could be described by authors as a series of rules and as a series of bodies of law. If there were a "legal theory" as such, then it concerned the antiquity of the common law and artificial reason. "Law" was not a unitary system, but a particular form of reasoning. Problematically, however, this approach explained little

52 See, for example, Salmond's favourable comments on continental jurisprudence which run throughout the whole of the first two chapters of Jurisprudence, commencing at 13: Jurisprudence 7 ed, above 1, 13.

53 Ibid, 2 ed, Appendix V; 7 ed, Appendix VII.

54 See Barbara Shapiro "Law and Science in Seventeenth Century England" (1968-9) 21 Stanford LR 727. Coke's work could not be viewed in this light. While highly influential, it was not a treatise. Rather, the Institutes are perhaps best described as a summa: the first Institute being of course a gloss on Littleton. Michael Lobban goes as far as to suggest that for Coke to "set down a complete defining treatise would have contradicted his idea of what the common law was about": Michael Lobban The Common Law and English Jurisprudence 1760-1850 (Oxford University Press, Oxford, 1991) 6.

55 Lobban, ibid, 3.

56 See, for example, Richard Aston Placita Latine Redicica (H Twyford, T Dring \& John Place, London, 1661) or even Sir Matthew Hale Historia Placitorum Coronce (2 vols, F Gayles, T Woodward, C Davis, The Savoy, London, 1736).

57 Lobban, above n 54, 2. 
of what law was about, or how its practical functioning could be explained. Dissatisfied, $18^{\text {th }}$ century lawyers took up the task of determining what law was about and of putting the law into a systematic framework "to show that it had rationality and comprehensiveness." 58

In utilising a structure common to institutional writings, Salmond situates himself within that long tradition of the English treatise. ${ }^{59}$ As with Blackstone and others, Salmond places the English legal system within an Institutional structure. Salmond commences with the science of jurisprudence, looks to civil law, the administration of law, sources of law, the State, then from Chapter $\mathrm{X}$ onwards, largely follows the format of persons, things and actions which characterises the Institutist framework. This stretches beyond Blackstone to Hale before him.

This structure is also characteristic of the German Pandectist movement of the $19^{\text {th }}$ century. Salmond's eclectic sources were not only English. Salmond's Jurisprudence was written towards the end of a period in which many analytical texts were influenced, particularly in regard to the systematisation of the law, by the German Pandectists. While there is some evidence of the influence of German literature of the time on Austin, it seems not to have been significant, particularly in The Province of Jurisprudence Determined. ${ }^{60}$ One may have thought that the turn from natural law to positive law might have been influenced in Austin by the similar turn earlier in the century in Germany, particularly in the influential work of Savigny. However, there were English writers with similar ideas at the time, and these appear to have been more influential. Austin did clearly read German law. His library contained all the major authors of the first part of the $19^{\text {th }}$ century. However, Schwartz argues that while he was interested in specific areas of doctrine - for example the interpretation of real and personal rights - he had "an inadequate appreciation of the extent to which the Germans had arrived at general statements of legal science which could offer him a model for his purpose." ${ }^{61}$ Nevertheless, the growing importance of the German work in the mid-part of the century is illustrated by the fact that its influence is clearly visible in Austin's later work on the clarification of particular concepts, such as legal personality. ${ }^{62}$

By the time of Salmond, the influence of German scholarship was strong. While there exists a considerable body of scholarship on the impact of the Pandectists in particular on American scholars (both contemporary and current), its influence on others in the common law world remains

58 Ibid, 12.

59 Sir William Blackstone Commentaries on the Laws of England (Wayne Morrison ed, Cavendish, London, 2001 (1769)).

60 W L Morison John Austin (Edward Arnold, London, 1982) 61-62.

61 Andreas Schwartz "John Austin and the German Jurisprudence of his time" (1934-5) 1 Politica 178, 190191.

62 Morison, above n 60, 62. 
relatively unexplored. ${ }^{63}$ In Germany a number of different schools of legal science (or Rechtswissenschaft) emerged that disputed both the relations between the historical and conceptual approaches to legal science and the status of legal science itself. Within the Anglo-American world, however, little distinction was made by those interested in the ideas of Rechtswissenschaft as to these different schools. In fact, as Reimann makes clear, while there was general consensus (particularly in America) as to the importance of German ideas. there was "surprisingly little understanding of what $19^{\text {th }}$ century German legal science really was." ${ }^{64}$ Again, a glance at Appendix V of Jurisprudence reveals that Salmond was more than aware of the important works of Rechtswissenschaft. Appendix V, on Salmond's own description, was both "by way of explanation of the references contained in the text and notes, and partly as a guide to the literature of the subject." 65 While the references in Jurisprudence are sparse by modern standards, it is clear from Appendix V that a number of important works of Rechtwissenschaft receive favourable annotation (Holtzendorff, Jhering, Puchta, Savigny, Thibault, Vangerow and Windschied all get mentioned as does Pothier - although there is no substantive discussion of their work in the text).

How much should be drawn from this is debatable. As with many jurisprudential transplants, it is often the form or style of jurisprudence that is received and put to local use and Salmond translates the style of the Pandectists into an essentially English tradition of treatise writing. In the seventh edition of Jurisprudence (1924), Salmond offered a slightly expanded conspectus of the links between English and foreign jurisprudence. ${ }^{66}$ There, in addition to linking analytical jurisprudence to principles of legal dogmatics or exposition, he notes the links between English jurisprudence and foreign jurisprudence. In particular, he points to those aspects of Rechtswissenschaft concerned with legal encyclopaedia (Arndts, Puchta). These are linked to general jurisprudence. Second, he mentions the Pandektenrecht. Third, he refers to those portions of the treatises devoted to the codes of law that deal with first principles. Fourth, he notes that the

63 See Smith "Four German Jurists" (1895) 10 Pol Sci Quarterly 664; J Beale "The Development of Jurisprudence During the Past Century" (1905) 8 Harv LR 271; Stefan Reisenfeld "The Influence of German Legal Theory on American Law: the Heritage of Savigny and His Disciples" (1989) 37 Am J Comp L 1. See generally the work of Marcus Reimann and in particular Marcus Reimann "Nineteenth Century German Legal Science" (1990) 31 Boston College LR 837. Duxbury considers that "interesting and enduring jurisprudential developments were occurring" outside England. He points to Austria (Kelsen) and the little known Scandinavian realist school: Neil Duxbury "English Jurisprudence Between Austin and Hart" (2005) 91 Va L Rev 1, 2-3. Duxbury does refer to the German tradition, but suggests only that the "inspiration of the analytical tradition was probably first evident in the work of ... Bierling": 6. While Bierling was an influential figure, the tradition well pre-dates that time.

64 Reimann, ibid, 838-839. However, see Hunter, above n 12, for a re-description of the German Enlightenment that does play close attention to the status of public law jurisprudence and its relation to the "civil enlightenment" of Pufendorf and Thomasius and the rival "metaphysical enlightenment" of Kant.

65 Jurisprudence 2 ed, above n 1, 495; Jurisprudence 7 ed, above n 1; 560.

66 Ibid, 2 ed, 6-7; 7 ed, 9-16. 
Rechtsphilosophie or philosophie du droit, whatever their dissimilarity, are united in their difference from English jurisprudence as their central concern is with the theory of justice not civil law. For Salmond, it is the civil jurisprudence of the $18^{\text {th }}$ century (Grotius, Pufendorf, Thomasius and, surprisingly, the protestant neo-scholastic Wolff) and not the metaphysics of Kant and the Kantians that prove to be the forebears of what has become English analytical jurisprudence. This is so largely because in its emphasis on 'political law' or public law (Staatsrecht, ius publicum) such natural law jurisprudences address civil justice and can be transmuted, by Salmond himself, into a civil jurisprudence. ${ }^{67}$

In the end, little of Salmond's Jurisprudence is directly expressed directly in the language of 'political' or public law. While the State is given prominence in the ordering of Jurisprudence from the second edition onwards, the elaboration of the understanding of the State is rendered in a form taken from the private law exposition of the Pandectists. ${ }^{68}$ While this could be viewed as an eclectic use of the Pandectists it was not an unthinking incorporation of German thought (shorn of its subtleties). Drawing on the Pandectists allowed Salmond to retain many of the ideas of the German political jurisprudence, but present it as an expository Institutist jurisprudence. For Salmond, one draws out the general principles from law by being a Pandectist and the drawing out of first or general principles was the principle task of the jurist.

The office of the jurist, therefore, is delimited by the task of the exposition of first principles of the law (properly speaking) in the service of the State in the 'English' manner. This task is both the telos and the limits of office. The 'English' manner is analytical jurisprudence. In this sense, analytical is primarily arrived at through genre. For Salmond it is State-centred and eclectic. It depends on maintaining appropriate distinctions between first principles and metaphysics and between the intellectual content of law and its history and evaluation. Most importantly, the jurist as legal scientist must be able to maintain a form of analysis that distinguishes law from justice, but also recognises the intimate historical and ethical connections between law and justice. In the hands of the metaphysicians, this would involve a training in an unworldly ethic of critical jurisprudence, but for Salmond it is a training in a worldly ethic. What then are the protocols of this worldly ethic and how does Salmond perform it?

67 Ibid, 2 ed, 7; 7 ed, 15. Despite this being a definitive location by Salmond of his own jurisprudence, it is removed without more by Fitzgerald in the $12^{\text {th }}$ edition: John Salmond (P Fitzgerald ed) Jurisprudence: or the Theory of the Law (12 ed, Stevens \& Haynes, London, 1966) when the text is defined as a textbook and not a treatise: vii [Jurisprudence $12 \mathrm{ed]}$.

68 In the first edition the State was considered in the Appendix. From the second edition it appeared in chapter 5. 


\section{THE PERSONA OF THE JURIST, SALMOND'S CIVIL JURISPRUDENCE AND THE ELABORATION OF WHAT LAW IS ...}

The third part of the article takes up the question of the conduct of life of the jurist and inauguration in a different way. Where the first part examined the office of the jurist, this part considers the persona - the type of character, capabilities and performances that are required to fulfil the office of jurist well. The office of Salmond's jurist is notable both for its allegiance to the will of the State and for the centrality given to the analytical jurisprudence. The relationship between persona and office can be engaged in a number of ways. Most simply, it can be figured in terms of the requirements of office. It might be expected, then, that for Salmond the persona of the jurist must be capable of providing the logical and rhetorical techniques for the naming of what law is and delimiting the requirements of the administration of civil justice. However occupation of office for Salmond also requires an ethic of office. This requires the exercise of prudence and judgment on the part of the jurist rather than simple compliance. This aspect of the persona of the jurist can be understood in terms of character and ethos. In writing about the persona of the philosopher in classical philosophy, Pierre Hadot has identified 'work on the self' as being central to the task of philosophy and to the formation and maintenance of a philosophical persona ${ }^{69}$ Since Cicero, it has also been an important theme in the training of the persona of the jurist. ${ }^{70}$ The nearest that Salmond comes to addressing these issues in Jurisprudence is in the various considerations of the relations between authority, law and ethics. For Salmond, English analytical jurisprudence does not exhaust the repertoires of engagement open to the jurist to fulfil their office. It is also possible to deploy, when appropriate, historical and ethical jurisprudence as well as ethical science.

This part of the article considers first the character and ethos of the jurist and second some of the capabilities and repertoires of engagement of Salmond's jurist. The first section proceeds by way of a set of contrasts between the Kantian persona of the philosopher and that of the civil jurist. For Salmond the Kantian philosopher, as metaphysician, provides a counterpoint to much of his own jurisprudence. The persona of the civil jurist - expressed in the work of Pufendorf and Thomasius, comes close to Salmond's jurist. However, somewhat tentatively, and quite conventionally, it is suggested, the model of Salmond's jurist might be found in the English latitudianarian attitudes to religious - here ethical - authority. Ethics is indeed important to the State and its law, but it is not necessarily the case that it is always desirable that it be represented in its true form in civil law. The jurist, like the judge, must be able to decide how to engage this relation between ethics and civil

69 Pierre Hadot Philosophy as a Way of Life: Spiritual Exercises from Socrates to Foucault (Blackwell Publishers, Oxford, 1995) ch 2. The theme of conduct of life is also central to the work of Max Weber: see, for example, Wilhelm Hennis Max Weber: Essays in Reconstruction (Allen \& Unwin, London, 1988).

70 Robert W Cape Jr "Cicero and the Development of Prudential Practice" in Rober Hariman (ed) Prudence: Classical Virtue Postmodern Practice (Penn State University Press, Pennsylvania, 2003) 35. 
law. The second section of this part notes some of the repertoires of engagement of the jurist in maintaining the relationship between ethics and the office of jurist.

\section{A Character, Ethos}

Questions of character and ethos do not sit easily with contemporary analytical jurisprudence if only because the aspirations of legal science seem characterless. ${ }^{71}$ However, $19^{\text {th }}$ century jurisprudence need not be treated as being devoid of doctrine or a paedeia of character. The analysis of the first principles of law, the use of reason, and the bracketing off of ethics and history, provide a model of juristic conduct and training and not simply of access to unmediated reason. However, while Salmond clearly engages with issues of ethos and character relating to the persona of the judge, the persona of the jurist is less clearly elaborated. The character of Salmond's judge is addressed quite generically in terms of impartiality, rectitude and honesty in the devotion to the administration of justice. ${ }^{72}$ The character of the jurist can also be phrased in much the same terms although the office of jurist is not bound by oath.

Given Salmond's specific assertion of filiation to the anti-metaphysical civil philosophy and natural law jurisprudence of Hobbes, Pufendorf and Thomasius, it would be no surprise to find that Salmond's English jurist shared some of the attributes of the worldly ethic of State developed within that tradition. ${ }^{73}$ This de-sacralised jurisprudence sought to represent the authority of the State in terms of the maintenance of civil peace. ${ }^{74}$ It also sought to develop a teaching that placed emphasis on the government of conduct rather than the government of the soul, as had been the case with church and university metaphysics. Such a jurist must be capable of conducting themselves, in matters of law and public order, without reference to an authority transcendent to the State. This would involve the capacity to suspend, for the purposes of office, an enthusiastic commitment to religious belief, questions of conscience and personal belief. In short, the persona of the jurist was trained in the restraint of the passions, subordination to State interests and self-government by civil manners. The civil jurist, magistrate and counsellor alike would share these attributes. ${ }^{75}$

71 Nigel Simmonds Decline of Juridical Reason (Manchester University Press, Manchester, 1986). Salmond imagines his own work to resist formalism: Jurisprudence 7 ed, above n 1, 8.

72 Donald R Kelley The Human Measure: Social Thought in The Western Legal Tradition (Harvard University Press, Cambridge MA, 1990).

73 Jurisprudence 2 ed, above n 1, 8; Jurisprudence 7 ed, above n 1, 14-15. See also David Saunders and Ian Hunter "Bringing the State to England: Andrew Tooke's translation of Samuel Pufendorf's De officio hominis et civis" (2003) 24 History of Political Thought 218.

74 "Societies can exit only under the shelter of the state and the law and the justice of the state is a permanent and necessary condition of peace, order and civilisation": Jurisprudence 7 ed, ibid, 113 and see generally Jurisprudence 2 ed, ibid, 66.

75 See generally Jeffrey Minson "Civil Prudence, Sovereignty and Citizenship in the Justification of Civil Forfeiture" (2006) 29 UNSW LJ 61. 
However, Salmond's claims of an inheritance for his general jurisprudence are more eclectic than reference to the directly anti-metaphysical polemics of the 'civil' philosophers might suggest. The later editions of Jurisprudence emphasised a rather more expansive account of the persona of the jurist. While the office of the jurist is generally subordinate to the will of the State, for Salmond, unlike the 'civil' philosophers, the State itself had an ethical agency linked with the administration of justice. Although the administration of justice has become increasingly "justice according to the law", legal justice is viewed by Salmond as a more or less "imperfect realisation" of justice as the "ideal and truth" of the general welfare of mankind. ${ }^{76}$ The persona of Salmond's English jurist must be capable of maintaining something of this relation between law and ethics (justice or right). In the seventh edition, for example, Salmond adds a brief discussion of ethics. ${ }^{77}$ In the introduction to that edition, Salmond points out that his doctrine has treated natural right or justice as "necessarily involved in the idea of civil law itself", ${ }^{78}$ whereas in earlier editions he had: ${ }^{79}$

treated the nature and validity of the conception of natural justice as one of the datum or postulates of jurisprudence but not properly examinable by that science, but pertaining exclusively to the domain of ethics. Further reflection [had satisfied him] that it is not permissible for a book of jurisprudence thus wholly to ignore the ethical implication of the subject.

It may be that analytical jurisprudence, as the exposition of the fundamental principles and conceptions of what law is, can treat natural justice and ethics as given (in the sense of beyond dispute for legal science). A book of jurisprudence, however, must have more. The 'ethical implication' - its effect on human welfare - could usefully be understood in terms of the capabilities of the English jurist to engage in ethical and historical jurisprudence. There are situations when it is necessary to consider natural justice since it gives us our ethical implication. ${ }^{80}$

A second topic in which the persona of the jurist requires the development of specific attributes is in relation to the use of reason. Analytical jurisprudence provides a way of delimiting the scope of law by revealing the fundamental principles and the logical form of the law. The status of this legal science as a knowledge is not easy to determine. On the one hand, legal philosophy is viewed as a department of philosophy. Its logic and reason and the elaboration of what law is need only be viewed as a local logic. The re-casting of jurisprudence between First Principles and Jurisprudence in terms of abstraction would certainly suggest this interpretation. So too would the elaboration of

76 Jurisprudence 7 ed, above $n$ 1, 41, 58.

77 Ibid, 7 ed, 58-74.

78 Ibid, $\mathrm{x}$.

79 Ibid, $\mathrm{x}-\mathrm{xi}$.

80 For Salmond, natural justice becomes imperative through the exercise of human authority: "[t]he legal justice of the state is natural justice armed", ibid, 64. The exercise of this authority is judicial. 
the categories of English common law and Roman law in terms of the civil law of a territory. ${ }^{81}$ Likewise, the definition of law in terms of the body of principles recognised and applied by the States in the administration of justice also suggests analytical jurisprudence is a method. On the other hand, Salmond also wrote as if reason and logic are foundational in a stronger sense. The distinction between formal and material aspects of law used in First Principles is not entirely abandoned in Salmond's analysis of the source of law. It is logic and reason, and not history, that establish the source and form of law (the power and will of the State) ${ }^{82}$ More exorbitantly, Salmond also reminds the reader that "[i]t must be borne in mind that in the beginning the whole earth was without form and void, and that science is concerned not with chaos but with cosmos."83

It is tempting to link the attributions of reason and right to a Kantian project of 'pure reason' that exists independently of empirical, historical and ethical concerns of character. ${ }^{84}$ In making claims to legal science, much analytical jurisprudence has proceeded on this basis. It will be suggested here that this is not appropriate. First, analytical projects of jurisprudence, Kantian or otherwise, do engage a juristic persona. The question is of what kind. Second, Salmond does offer a broad account of the persona of the jurist that can be contrasted with that of the Kantian persona of the philosopher. It is this persona that enables the office of the jurist, judge and legal adviser to be fulfilled in relation to the administration of justice.

Rather than pursue the Kantian project of critical reason, some attention is given here to the persona required in order to engage in Kantian ethics. ${ }^{85}$ Ian Hunter has recently pointed to the ways in which the 'rationalist' philosophers of the German enlightenment, Leibniz, Wolff and Kant, continued the traditions of university and church metaphysical ethics. ${ }^{86}$ For Hunter, developing the work of Hadot, the Kantian metaphysics of morals is not simply a possible theory of critical reason

81 Jurisprudence 2 ed, above n 1, 9 - and also, it might be imagined, analytical jurisprudence positivism.

82 Ibid, 51.

83 Ibid. Hardly less grandiose are claims made for legal science in the aid of legal codification and the building of the "perfect legal system" in "The Literature of the Law", above n 23, 208 :

"Through centuries of slow development we have gathered together the materials for the greatest system of law that the world has ever known. Is it too much to hope that we are now approaching the end of that long era and that we are ready to build up these materials into a stately monument of perfect form which will endure forever as one of the great contributions of this century to the cause of truth, justice and civilization?"

84 Pound, above n 9, 99.

85 Ihering's dismissal of Kant is illustrative: Rudolph von Ihering Law as a Means to an End (Boston Book Company, Boston, 1913) 37-40.

86 See also Jacqueline Rose Dialectic of Nihilism (Blackwell, Oxford, 1984). 
or of the moral subject; it is an engagement in the cultivation of a particular persona or moral self. ${ }^{87}$ Kant's philosophical persona continues a long tradition of metaphysical anthropology which understands human beings as a union (or a split) of a rational nature of intelligible being and a sensible nature consisting of sensuous inclinations. Philosophical training was a training in the 'pure willing' of unconditional good, freed from empirical desire or outcomes.

While the formulation of ethical action in terms of 'unconditional willing' seems to be an invitation to a contemplative life, it also provided a training in the recognition of the duties of the categorical imperative. Such a philosophical persona was required to produce and gain access to the realm of ethical duties that exist independently of the realm of ends. Kant's categorical imperative, "act only in accordance with that maxim through which you can at the same time will that it become a universal law", commands without ends. ${ }^{88}$ The intuiting of the categorical imperative, as Hunter presents it, can be viewed as an exercise in self-transcendence. ${ }^{89}$ Its purpose is to orientate thought towards the possibility of a world of rational beings and laws: a "universal kingdom of ends in itself." 90 It is this that allows the Kantian philosophical persona to conduct itself, and to judge as if it were subject only to the laws of the intelligible world - freedom and autonomy of will. ${ }^{91}$ This conduct and reasoning, for Kant, is to be considered the true public reason addressed to the enlightened world of rational beings. ${ }^{92}$ It is set before the private reasoning of the State which addresses only particular interests of the State. ${ }^{93}$ Analytical jurisprudence, like Kant's metaphysics of morals, provides training in conduct and not simply a method for the exposition of fundamental principles or concepts.

\section{B Repertoires of Engagement}

There is much in this account of the homo duplex that finds resonance in $19^{\text {th }}$ century common law thought. A Kantian dedication to the establishment of rational communication in a realm of intelligible being freed from sensuous distraction is a specific theme of analytical jurisprudence, of

87 Ian Hunter "The Morals of Metaphysics: Kant's Groundwork as Intellectual Paideia" (2002) 28 Critical Inquiry 908, 914 ["The Morals of Metaphysics"].

88 Immanuel Kant Practical Philosophy (Mary J Gregor trans \& ed, Cambridge University Press, New York, 1996) 72-73, discussed in "The Morals of Metaphysics", ibid, 921. See also Salmond's brief critical comments on what he takes to be Spencer's Kantian account of justice: Jurisprudence 7 ed, above n 1, 7374.

89 "The Morals of Metaphysics", ibid, 922.

90 Kant Practical Philosophy, above n 88, 108, cited in ibid, 928.

91 Kant Practical Philosophy, ibid, 100, cited in "The Morals of Metaphysics", above n 87, 925.

92 See Immanuel Kant "The Contest of Faculties" in Hans Reiss (ed) Kant's Political Writings (HB Nisbet trans, Cambridge University Press, Cambridge, 1991).

93 See Immanuel Kant "An Answer to the Question: 'What is Enlightenment"' in ibid. 
neo-Kantian jurisprudence and codification. ${ }^{94}$ There was also a rather more diffuse Kantian theme in the work of public philosophy in the social utilitarians Mills and Spencer. ${ }^{95}$ However, for all that Salmond does allow for the possibility of a higher ethical-rational persona ("persona duplex") to engage in law, compared to Kant's formulation of the training in the metaphysics morals, Salmond's training in analytical jurisprudence is for the most part mundane - worldly. For Kant, the training in the metaphysics of morals was an engagement in gaining access to the intelligible world of rational beings. It is also central to fulfilling the office of public reason. Perhaps it would be more appropriate to consider Salmond as providing a persona with a range of attributes to fulfil a diffuse office. The training implied in Salmond's jurisprudence does not seem to be designed to give access to a higher order of rational law. Rather it presents a training both in the power of exposition and in the recognition of the limits of office. There is little sense that this worldly restriction of the scope of ethics engenders a great need of ethical self-transformation of the kind required of the Kantian philosophical persona, nor is there the sense of a radical restriction of persona according to the requirements of office. While reason and the fundamental principles and concepts of law form the substance of jurisprudence, the modes of the English jurist are not treated as necessarily exemplary. The relative lack of concern with ethics is expressly criticised. ${ }^{96}$ However, while a lack of attention to ethics is treated as a failing, it is not sufficient to invalidate legal science as such or to prevent the writing of books of English jurisprudence. Ethical acuity provides a better ability to appreciate what is to be written about legal justice.

The formulation of the persona of the jurist in terms of a range of eclectic attributes should not be taken as reducing the importance of logic and reason. Rather, it draws attention to the ways in which the occupation of the office of the jurist requires the development of a certain kind of prudence - a negotiation of the terms of office and the limits of legal science. ${ }^{97}$ The claims of legal science to reason are leavened and engaged with practical "administration of justice among mortal and imperfect men."98 By contrast the Kantian persona is trained to transcend office in order to subject their higher intellectual natures to the command of ethics. The negotiation of office that takes place can be seen in Salmond's treatment of the authority of law in relation to reason, justice

94 See, for example, Roscoe Pound "Fifty Years of Jurisprudence" (1937) 50 Harvard Law Review 557; (1938) 51 Harvard Law Review 444.

95 See, for example, Roscoe Pound "The Progress of the Law Analytical Jurisprudence: 1914-1927" (1927) 41 Harvard Law Review 174, 192.

96 "It is, I conceive, not the merit but the defect of English jurists that they have attempted to deprive the idea of law of that ethical significance which is one of its most essential elements." First Principles, above n 1, 10 .

97 Salmond links prudence with personal self-interest in opposition to justice. Prudence here refers to the ability to occupy office.

98 "Literature of the Law", above n 23, 204 
and fact. Where these concerns might be viewed in terms of epistemology, they are treated by Salmond as questions of juristic character.

Salmond does not offer a detailed consideration of the relationship between justice and law. In the seventh edition of Jurisprudence he offers a brief criticism of Herbert Spencer's attempt to deduce the ambit of justice from his principle of equal liberty ("everyman is free to do that which he wills, provided he infringes not the equal freedom of the other man"). ${ }^{99}$ Instead of rejecting Spencer's approach as metaphysical, Salmond doubted the efficacy of attempts to "limit deductively and scientifically the proper boundaries and territory of civil law", preferring instead "the formulation of principles as to the relative advantage and disadvantages of legal restraint on the one hand and natural liberty on the other, in order that the issue may be better judged in each individual instance in which it arises for decision." 100 While this, again, expresses a commonplace and reinforces the importance, for Salmond, of the persona of the common law judge in considering the persona of the jurist, it also shows something of Salmond's sense of the limits - and pragmatics - of analytical jurisprudence.

The centrality of the persona of the jurist allows for the narration of judgment and reason to be presented as juristic commentary. Salmond's account of the relationship between law and fact, and law and right is typical in this aspect. Salmond's analysis of the relationship between law and fact reveals a stark deployment of the juristic persona. For Salmond, questions of fact are to be understood as all that is not reducible to a determinate decision of law. Facts are those points of decision that are not: (1) determined as questions of principle or rule; or (2) those moral questions of truth and justice determinable at the discretion of the judge. The structure of the assertion is centred on the determination of law by the judge, and the genetic and logical argument records a movement, as with Salmond's treatment of natural justice, from the determination of fact and justice and truth to the determination of legal principle. ${ }^{101}$ A rather more nuanced account of the place of the jurist and persona required to fill it can be found in Salmond's treatment of right and justice and of legal right. First, it defends an account of natural right and natural justice; second, an account is offered of how natural right is brought into the domain of civil law; and third, an account is given of both the analytical ordering of legal right and the requirements of good sense. Salmond's analytical account is well known. He is credited with adapting the analysis of the 'content of a right' developed from the German Pandectists, particularly the neo-Kantian jurist Bierling, by constructing a system of correlative rights. Less well remembered has been the way in which the requirements of judgment of right were given shape by ordering the correlative rights in terms of welfare: advantage and disadvantage. Legal advantages, including right in the wider sense, involved rights, liberties and

99 Herbert Spencer Principles of Ethics (vol II, Williams \& Norgate, London, 1893) 46.

100 Jurisprudence 7 ed, above n 1, 73.

101 Ibid, 82. 
powers. The burdens took the form of duties, disabilities and liabilities. ${ }^{102}$ This practical ordering is still a claim of logic but one which was viewed from the position of the need to maintain various kinds of practical judgment in relation to justice and right.

By way of concluding this section, two further comments can be made about the presentation of this persona. At a very general level, Salmond's jurisprudence and jurist were optimistic rather than melancholic. ${ }^{103}$ His teaching - as noted by Frame - was designed to bring light, or at least clarity, to legal thought. Students were not expected to renounce ethics or truth in the study of law, but to be capable of suspending judgment for the purpose of elaborating the intellectual elements of law. While analytical legal science sought the exposition of the logic of law, for Salmond, the preferred mode of exposition was a commentary which brings the judicial authority of law into relation with justice. This commentary takes place from within the civil law, a civil law that was to be considered secondary to both natural justice and the power of the State. The jurist, as legal scientist, has the task of revealing the past, present and future of the law.

Perhaps the last words on the persona of the jurist should be left to Salmond. In "The Literature of the Law", a published version of a lecture delivered to the American Bar Association in 1922, Salmond briefly considered the attributes of the critical jurist, or at least the critical jurist who would prepare the ground for the codification of the common law. It is the jurist, or at least jurists like Ulpian, Paul and Papinian, who were the true writers of law - law of the future - more so than the mere expositors and historians of law. The production of the code, Salmond writes: ${ }^{104}$

will require learning, acumen, legal insight, and sound practical judgment. The crank, the faddist, the visionary, the mere logician, the unpractical idealist, must have no hand in them. Learning, acuteness, logical precision and philosophic insight must go hand in hand with the humbler virtue of practical good sense. For nothing is good law, however perfect it may be from the point of view of logic, unless it is such to admit of practical application in the somewhat rough and ready business of the administration of justice among mortal and imperfect men.

It might be remembered that such jurists - in dealing with the profusion of laws and in honouring the spirit and work of their forbears - were to create in the statutes of the common law "a stately monument of perfect form which will endure forever as one of the great contributions of this century to the cause of truth, justice and civilization."105

102 Jurisprudence 2 ed, above n 1, 186-190; Jurisprudence 7 ed, above n 1, 246-251.

103 See Peter Goodrich "Law Induced Anxiety: Legists, Anti-Lawyers and the Boredom of Legality" (2000) 9 Social Legal Studies 143. As to the depressive illness and recovery of Mrs Salmond see Frame, above n 34, 240.

104 "Literature of Law", above n 23, 206.

105 Ibid, 208. 
In paying attention to the office and persona of the jurist, this article has, for the most part, been concerned with resettling Salmond's jurisprudence in the context of the inheritance of $19^{\text {th }}$ century English analytical jurisprudence. Paying attention to the office and persona of the jurist provided a heuristic point of organisation for a number of considerations of the historical understanding of jurisprudence. The first amongst these is that $19^{\text {th }}$ century jurisprudential writings are indeed concerned with issues of office and persona in a meaningful way. It has been suggested that Salmond was engaged with such issues in his writing. Other jurists have little interest in these matters - the genres of jurisprudence writing are more varied than has often been characterised by philosophical polemics about positivism and analytical jurisprudence.

The polemics of jurisprudence, it has been argued here are better phrased in terms of rival conducts of legal life. The contrasts described in this article between the personae of the Kantian jurist and the civil jurist draw on a long tradition of polemic and teaching about the proper conduct of life. Ian Hunter and others have argued for the enduring significance and rivalry of two personae: the Platonic-Christian persona of the homo duplex directed toward accession to a higher world of rational being and the epicurean persona directed towards managing the passions of worldly existence. The Kantian jurist and the jurist of the civil philosophers provide $19^{\text {th }}$ century examples. In this context, the persona of Salmond's jurist has not been easy to discern. Without offering a definitive assessment it was argued that the persona of Salmond's jurist is more securely directed to the worldly matter of the office of jurist than the transcendent concerns of rationality. In this respect Salmond's jurist is indeed quite English. It is a persona that could be recognised in the juristic writings of such figures as Richard Hooker and Matthew Hale, or indeed such contemporaries of Salmond as Gray.

A question remains as to how much can be explained by interpreting the genres of $19^{\text {th }}$ century jurisprudence in terms of a 'conduct of life' of the jurist, or for that matter how much of the 'conduct of the life' of the jurist can be explained through the genres of jurisprudence. In this article it has been assumed there is something to be gained in marking the historical contours of the persona of the jurist. In doing so, it has given weight to those accounts of office and persona that emphasise institutional accounts of office and prudential accounts of the repertoires of the persona. Such a mode of history writing is not particularly sympathetic to transcendent accounts of either office or persona.

Finally to return to the question of inheritance that opened this article. It could be said that not much of Salmond's understanding of the office and persona of the jurist, and perhaps also of the writing of jurisprudence, receives attention. The text of Salmond's Jurisprudence remained in print for some time. The $12^{\text {th }}$ edition was edited by P J Fitzgerald and published in $1966 .{ }^{106}$ Further 
editions have been published in India. ${ }^{107}$ However, even a brief examination of the editions of Jurisprudence edited after Salmond's death, shows that those aspects of the text that deal with the office and persona of the jurist discussed in this article have been considered unnecessary to the text. However it was Glanville Williams, as editor of the $10^{\text {th }}$ and $11^{\text {th }}$ editions, who made the most incisive criticisms and changes to the text. ${ }^{108}$ Some editorial decisions were pragmatic. For example, the chapter on the State was removed in the $11^{\text {th }}$ edition to make way for a fuller discussion of precedent in the hierarchy of the courts. ${ }^{109}$ However, one consequence of this is that the link between civil law and the administration of justice is no longer clearly linked to the (limited) function of the State. As a result, it could be argued, the office of the jurist was detached from the functions of the State. ${ }^{110}$ In keeping with his rejection of metaphysics as verbal and inappropriate to jurisprudence, Williams also directed criticism towards the possibility of sustaining any account of truth or natural justice. ${ }^{111}$ As a consequence, much of Salmond's elaboration of the persona became redundant. ${ }^{112}$ While it is possible to argue that these editorial decisions reflect the passing of a view of English analytical jurisprudence, it is not the case that the analytical jurisprudence of, say, Glanville Williams or, for that matter Herbert Hart, was no longer concerned with questions of persona and office. ${ }^{113}$ Perhaps with renewed concern over the decline of the office of the jurist and offices of law, the denegation of limits of the administration of justice, and the continuing task of taking responsibility for the common laws of colonisation and decolonisation, Salmond's account of office and persona still has some resonance.

107 AK Sarkar (ed) Summary of Salmond's Jurisprudence (3 ed, Tripathi, Bombay, 1973, reprinted 1981).

108 John Salmond Jurisprudence (G Williams ed, 11 ed, Sweet \& Maxwell, London, 1957) Appendix V [Jurisprudence 11 ed].

109 Ibid, vii.

110 Salmond moved his consideration of the State from Chapter 9 to Chapter 5 from the second edition onwards: see Jurisprudence 2 ed, above n 1, v, ix.

111 Jurisprudence 11 ed, above n 108, ix, 524-626. In similar manner Salmond's discussions of ius gentium and natural law are treated only as philological: 523.

112 In the $12^{\text {th }}$ edition, PJ Fitzgerald excises almost all of Salmond's account of ethics and justice: Jurisprudence 12 ed, above n 67.

113 HLA Hart The Concept of Law (Clarendon, Oxford, 1961) clearly owes much to Salmond's Jurisprudence: see Frame, above n 34, 50. Hart's struggles to articulate the tasks of analytical jurisprudence in his response to Dworkin, published in the postscript to the second edition (Clarendon, Oxford, 1991), might have been more usefully defended in terms of office and persona rather than in terms of the faculties of knowledge. 